\title{
Five Types of Personality and the Locus of Internal Control in relation to Preeclampsia Pregnancy
}

\author{
Lusiana Meinawati ${ }^{1}$, Kusnanto Kusnanto ${ }^{2}$, Oedojo Soedirham ${ }^{3}$ \\ ${ }^{1}$ Doctoral Program of Public Health, Faculty of Public Health, ${ }^{2}$ Faculty of Nursing, ${ }^{3}$ Faculty of Public \\ Health, Universitas Airlangga, Mulyorejo, Surabaya, Indonesia
}

\begin{abstract}
Preeclampsia is one of the highest mortality factors for pregnant women. Hypertension, one of the main characteristics of preeclampsia, is the second main causes of maternal mortality at $27.1 \%$. During pregnancy, they will face physical and psychological stressors. One of the factors related to stress management is the woman's characteristics and the locus of control. This study aims to identify the relationship between the five types of personality and the locus of internal control in relation to preeclampsia in pregnancy. This study used a cross-sectional design. The population of this study consisted of pregnant women with preeclampsia who came to the independent midwifery practices in Jombang; 135 women total. The sample was selected using the total sampling method. The data was analysed by regression analysis. The independent variables related to preeclampsia included neuroticism $(p=0.003 ; \operatorname{Exp}(B)=11.234)$ and the negative internal locus of control $(\mathrm{p}=0.000 ; \operatorname{Exp}(\mathrm{B})=11.387)$. It is expected that midwifery professionals can provide counselling services effectively and efficiently in relation to performing antenatal care services.
\end{abstract}

Keywords: personality, locus of control internal, pregnancy, preeclampsia.

\section{INTRODUCTION}

Preeclampsia is one of the highest mortality factors for pregnant women ${ }^{1}$. Hypertension, one of the main characteristics of preeclampsia, is the second main cause of maternal mortality at $27.1 \%$, after haemorrhage $(30.3 \%)$ and before infection $(7.3 \%)^{2}$. According to the data of Survey Demografi Kesehatan Indonesia (SDKI) in 2007 and 2012, the Maternal Mortality Rate (MMR) in Indonesia was still high, by as many as 228 and 359 per-100,000 live births respectively. This number is still far from the target of the Millennium Development Goals (MDGs) 2015, which aims for 102 per-100,000 live births ${ }^{3}$.

According to the health profile of Indonesia's East Java Province in 2012 and 2013, the mortality rate was

\section{Corresponding Author:}

Lusiana Meinawati

Doctoral Program of Public Health, Faculty of Public Health, Universitas Airlangga, Mulyorejo, Surabaya, Indonesia

Email: lusiana85@gmail.com
97.43 per-100,000 live births and 97.13 per-100,000 live births respectively ${ }^{4}$. In Jombang City in 2017, there were 28 maternal deaths following live births. The number increased from 2016, with 17 deaths. The 28 deaths in 2017 were caused by preeclampsia ( 5 cases), haemorrhage post-partum (4 cases), eclampsia (3 cases), amniotic embolism (2 cases) and an ante-partum bleeding case, while the other 13 was caused by other co-morbidities. These cases must be considered to devise more effective initial assessments and interventions in order to decrease the maternal mortality rate caused by preeclampsia and eclampsia.

Pregnant women are one of the most vulnerable members of a community. During pregnancy, they will face physical and psychological stressors. Good stress management determines the success of the pregnancy. One of the factors related to stress management is the woman's characteristics and how far the woman can control her emotions in relation to overcoming the stress related to the physical alterations caused by pregnancy and for other reasons.

There are five basic personalities according to Goldberg, encompassing openness to experience, 
conscientiousness, extraversion, agreeableness and neuroticism, which affects people in the context of solving their problems ${ }^{5}$ The locus of internal control also influences the pregnant women's condition ${ }^{6}$ their commitments are influenced by their personality traits, as they are also known as emotional labour. The purpose of this study is to investigate the dominant personality traits in the company based on the Big Five Personality theory, to assess the level of employees' commitment to service quality (quality pledge. This study aimed to identify the relationship between the five types of personality and the locus of internal control with preeclampsia pregnancy.

\section{METHOD}

This study used a cross-sectional design. The study was conducted in Jombang Regency, from July to September 2016. The population of this study were all of the pregnant women with preeclampsia who came to the selected independent midwifery practices in Jombang, totalling 135 women. The sample was selected using the total sampling method. The instrument used was a questionnaire with a Cronbach's Alpha value of 0.862 . The data was analysed using regression analysis.

\section{RESULTS}

Table 1: Demographic characteristics of the respondents $(\mathbf{n}=\mathbf{1 3 5})$

\begin{tabular}{|c|c|c|c|}
\hline Characteristics & Parameters & $\mathrm{n}$ & $\%$ \\
\hline \multirow{2}{*}{ Age (years old) } & $18-35$ & 73 & 54.0 \\
\hline & $>35$ & 62 & 46.0 \\
\hline \multirow{2}{*}{ Pregnancy } & Primigravida & 44 & 33.0 \\
\hline & Multigravida & 91 & 67.0 \\
\hline \multirow{3}{*}{ Occupation } & Housemaid & 27 & 20 \\
\hline & Factory workers & 53 & 39 \\
\hline & Teacher & 55 & 41 \\
\hline \multirow{2}{*}{ Education } & Senior High School & 116 & 86 \\
\hline & College & 19 & 14 \\
\hline \multirow{2}{*}{$\begin{array}{l}\text { Locus Internal } \\
\text { Control }\end{array}$} & Positive & 53 & 39 \\
\hline & Negative & 82 & 61 \\
\hline \multirow{5}{*}{ Personality } & $\begin{array}{l}\text { Openness to } \\
\text { experience }\end{array}$ & 12 & 8 \\
\hline & Conscientiousness & 18 & 13 \\
\hline & Extraversion & 7 & 5 \\
\hline & Agreeableness & 30 & 22 \\
\hline & Neuroticism & 68 & 52 \\
\hline
\end{tabular}

Table 2: Results of logistic regression analysis

\begin{tabular}{|c|c|c|c|c|c|}
\hline Variable & B & S.E. & Sig. & Exp (B) & 95\%CI \\
\hline Neuroticism & 2.897 & 0.432 & 0.003 & 11.234 & $\begin{array}{c}2.899< \\
\text { OR }< \\
43.587\end{array}$ \\
\hline $\begin{array}{c}\text { Negative } \\
\text { ILC }\end{array}$ & 1.143 & 0.458 & 0.000 & 11.387 & $\begin{array}{c}1.897< \\
\text { OR }< \\
23.426\end{array}$ \\
\hline
\end{tabular}

Table 1 shows that most of the respondents were 18-35 years old (54\%). Most of the women had multigravida (67\%). Regarding occupation, most were factory workers (395) and had a senior high school level of education (86\%). The most common locus of control had was negative, and the most common personality was neuroticism (52\%).

Table 2 shows that the independent variables related to preeclampsia included the personality of neuroticism $(p=0.003 ; \operatorname{Exp}(B)=11.234)$ and the negative internal locus of control $(p=0.000 ; \operatorname{Exp}(B)=11.387)$.

\section{DISCUSSION}

1. Age: Based on age, the respondent's characteristics showed that the majority of the respondents were 18-35 years old. Age is a determinant factor influencing the health status of pregnant women. However, in preeclampsia cases, the mother's age does not influence occurrence. Instead, it is affected by other factors encompassing the environment, health record, parity, metabolism disorders, psychological conditions, and socialeconomic status ${ }^{7}$. The many occurrences of preeclampsia at a healthy age are due to most pregnancy and childbirth cases occurring between the ages of 18 and 35 years old. According to the Indonesian Ministry of Health, the age of pregnant women who are at the highest level of risk is mothers who are too young ( $<20$ years) or too old ( $>35$ years).

2. Pregnancy: The characteristics of the respondents based on their pregnancy showed that most of the respondents had multigravida pregnancy. Cunningham (2014) stated that the risk factors for preeclampsia are nullipara, the environment, socioeconomic conditions, seasonal influences, obesity, gemelli pregnancy, maternal age, impaired metabolism and a family history of 
preeclampsia or previous history of preeclampsia. A study conducted by Hindun (2015) showed that primigravida has a greater chance of developing by 2.875 times into preeclampsia compared with non-primigravida.

3. Occupation: The characteristics of the respondents based on their work indicated that most of the pregnant women work as factory workers. The risk factors for preeclampsia include their socioeconomic condition, in which one of the supporting factors is employment? ${ }^{7}$. Work as a factory worker is an activity that involves physical activity. In a factory, the conditions are always pressured, which is a factor that causes psychological disorders that affect maternal pregnancy. A study mentioned that mothers who work in the formal sector have better access to information about their health, more actively have a positive attitude and more independently take care actions ${ }^{8}$.

4. Education: The characteristics of the respondents based on education level was that the majority of respondents had a high school level of education. A person's level of education influences how a person makes decisions on the health problems that they experience. The lower the mother's education level, the less the mother has the desire to use health services. A study mentioned that mothers with a higher education level have better access to information about health. It makes them have a better decision-making process related to determining care planning for the duration of their pregnancy ${ }^{8}$.

5. Personality and Locus of Control: The regression analysis results showed that the independent variable allegedly related to the preeclampsia cases was the personality of neuroticism with $\operatorname{Exp}(B)=11.234$. It means that pregnant women with a neurotic personality are 11.387 times more likely to get preeclampsia. The negative ILC has a relationship with preeclampsia with $\operatorname{Exp}(\mathrm{B})$ 11.387. This means that pregnant women with a negative ILC have 11.387 times the probability of having preeclampsia.

Neuroticism is a personality in which a person can evaluate their ability to handle pressure or stress 9 . The positive characteristic of neuroticism is emotional stability. Individuals with emotional stability tend to be calm in facing problems, have self-confidence and firm principles. However, the negative characteristics of neuroticism are being easily nervous, depressed, not confident and easily changing their mind $\mathrm{d}^{5} \mathrm{~A}$ study proved that there is an influence between stress and the occurrence of hypertension in pregnant women ${ }^{10}$. This is because they are unable to overcome the problems faced by their mental, physical and emotional health.

The negative attributes of neuroticism as mentioned above show that the pregnant women were not ready to adapt to the physical and psychological alterations of pregnancy. It influences their mental and emotional health, and can affect their cardiovascular condition, increasing their blood pressure and thus, leading to preeclampsia ${ }^{11}$ who were matched for age and date of delivery. The incidences of diabetes, dyslipidemia, hypertension and cardiovascular events after pregnancy were identified from medical records after the date of delivery to the date of an event or the end of the study. $\lfloor n \backslash n R E S U L T S \backslash n T h e$ median follow-up duration was 9.8 years (interquartile 5.1-12.7 years.

The study showed that there was a relationship between negative locus of control and the incidence rate of preeclampsia. Locus of control is a condition where a person can control him/herself against the problem at hand. When a pregnant woman is unable to adapt to a problem, it means that the pregnant woman has a negative locus of control. The risk factors for preeclampsia are nullipara, the environment, socioeconomic conditions, seasonal influences, obesity, gemelli pregnancy, maternal age, impaired metabolism and a family history of preeclampsia or a history of previous preeclampsia, as well as psychological factors ${ }^{7,12}$.

\section{CONCLUSION}

Based on the results of the study, it showed that out of the five major properties of personality, neuroticism and having a negative internal locus of control were the variables most associated with the incidence rate of preeclampsia. It is expected that a midwifery professional can provide counselling services effectively and efficiently in relation to performing antenatal care services.

\section{Conflict of Interest: None.}

Ethical Clearance: The study passed ethical clearance from Ethical Committee of the Faculty of Publich Health, Universitas Airlangga, Surabaya, Indonesia.

Source of Funding: This study is self-funded by the researchers. 


\section{REFERENCES}

1. Masoura S, Kalogiannidis IA, Gitas G, Goutsioulis A, Koiou E, Athanasiadis A, et al. Biomarkers in pre-eclampsia: A novel approach to early detection of the disease. J Obstet Gynaecol (Lahore) [Internet]. 2012 Oct 4 [cited 2018 Aug 24];32(7):609-16. Available from: http://www. tandfonline.com/doi/full/10.3109/01443615.2012 .709290

2. Soedarmono YSM. The Indonesian approach to reduce maternal mortality. ISBT Sci Ser [Internet]. 2017 Feb 1 [cited 2018 Aug 2];12(1):272-80. Available from: http://doi.wiley.com/10.1111/ voxs. 12317

3. BKKBN. Survei Demografi dan Kesehatan Indonesia 2012 [Internet]. Jakarta; 2013 [cited 2018 Aug 24]. Available from: www.measuredhs. com.

4. Kementerian Kesehatan Republik Indonesia. Profil Kesehatan Indonesia Tahun 2016 [Internet]. Jakarta, Indonesia; 2017 [cited 2018 Aug 2]. Available from: http://www.kemkes.go.id

5. Fleeson W, Wilt J. The relevance of big five trait content in behavior to subjective authenticity: do high levels of within-person behavioral variability undermine or enable authenticity achievement? J Pers [Internet]. 2010 Aug 1 [cited 2018 Aug 24];78(4):1353-82. Available from: http://www. ncbi.nlm.nih.gov/pubmed/20545814

6. Ma'amor H, Achim N, Yunus NSNM, Hashim N, Haque A. The Influence of Personality Traits Towards Quality Pledge. Procedia Econ Financ [Internet]. 2016 Jan 1 [cited 2018 Aug 24];37:739. Available from: https://www.sciencedirect. com/science/article/pii/S2212567116300958
7. Taylor RN, Roberts JM, Cunningham FG, Lindheimer MD. Chesley's Hypertensive Disorders in Pregnancy [Internet]. Elsevier Science; 2014. Available from: https://books. google.co.id/books?id=eSCOAwAAQBAJ

8. Padila P. Buku ajar keperawatan maternitas. Yogyakarta: Nuha Medika; 2014.

9. John OP, Srivastava S. Paradigm Shift to the Integrative Big Five Trait Taxonomy: History, Measurement, and Conceptual Issues. In: Handbook of personality: Theory and research [Internet]. 3rd Editio. New York: Guilford; 2010 [cited 2018 Aug 24]. p. 102-38. Available from: http://moityca.com.br/pdfs/bigfive_john.pdf

10. Alizadeh Z, Feizi A, Rejali M, Afshar H, Hassanzadeh Keshteli A, Adibi P. The predictive value of personality traits for psychological problems (stress, anxiety and depression): Results from a large population based study. J Epidemiol Glob Health [Internet]. 2017 Nov 26 [cited 2018 Aug 24]; Available from: https:// www.sciencedirect.com/science/article/pii/ S221060061630154X

11. Kuo Y-L, Chan T-F, Wu C-Y, Ker C-R, Tu H-P Preeclampsia-eclampsia and future cardiovascular risk among women in Taiwan. Taiwan J Obstet Gynecol [Internet]. 2018 Jun 1 [cited 2018 Aug 24];57(3):364-9. Available from: https:// www.sciencedirect.com/science/article/pii/ S1028455918301013

12. Sukfitrianty, Aswadi, Lagu AMHR. Faktor Risiko Hipertensi Pada Ibu Hamil Di Rumah Sakit Hikmah Kota Makassar. Al-Sihah Public Heal Sci J. 2016;8(1):79-88. 